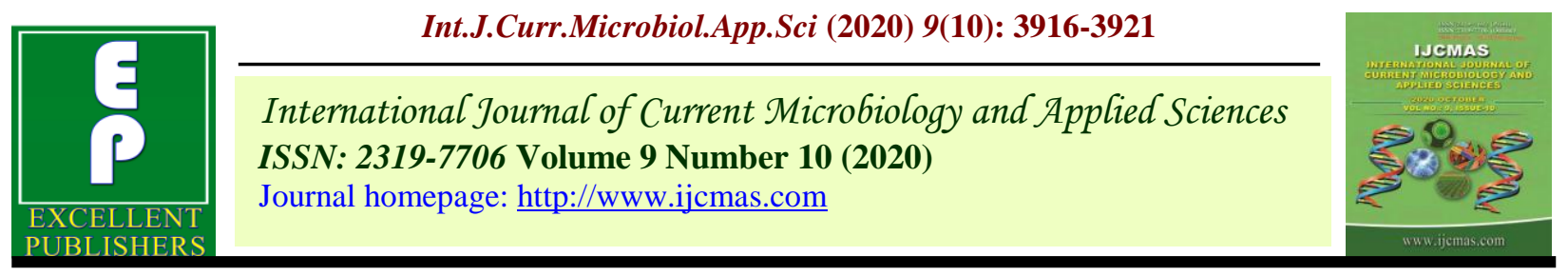

Original Research Article

https://doi.org/10.20546/ijcmas.2020.910.451

\title{
Study of White Rust (Albugo candida) Management Approach in Indian Mustard (Brassica juncea) at Farmers Fields through on farm Testing (OFT) at Farmers Fields
}

\author{
Sunil Kumar $^{1 *}$, Sushil Kumar Sharma ${ }^{1}$, Pankaj Sharma ${ }^{2}$ and P. K. Rai ${ }^{2}$ \\ ${ }^{1}$ Krishi Vigyan Kendra (ICAR-DRMR), Gunta-Bansur, Alwar, Rajasthan, India \\ ${ }^{2}$ ICAR-Directorate of Rapeseed-Mustard Research, Bharatpur, 321303 India
}

\begin{tabular}{l} 
Ke y w o r d s \\
White Rust \\
Albugo candida, \\
Mustard, \\
Brassica juncea \\
\hline Article Info \\
$\begin{array}{l}\text { Accepted: } \\
\text { 25 September } 2020 \\
\text { Available Online: } \\
\text { 10 October } 2020\end{array}$ \\
\hline
\end{tabular}

\section{A B S T R A C T}

In India, oilseed Brassica are grown over an area of about 6.3 million hectares with an annual production of 7.92 million tones with an average yield of $1304 \mathrm{~kg} / \mathrm{ha}$ whereas in Rajasthan it was still $1422 \mathrm{~kg} / \mathrm{ha}$. The severe attack of many diseases not only deteriorates the quality of the seed, but also reduces the oil content considerably. Among the diseases, white rust caused by Albugo candida (Pers. Ex Hook) O. Kuntze, is an important disease of a wide variety of Brassica crops. Its infection causes disfiguring white pustules on leaves, flowers stems and pod leading to yield losses. Mustard is an economic important crop in Alwar district of Rajasthan more than 2.5 lac ha area is under mustard cultivation. Management technology recommended for white rust disease has not much effective. Hence, looking for the improve disease management technology. So, there is need of assessment and refinement in technology through on-farm testing. The technology was evaluated through OFT during 2014-15 and 2015-16 cropping season in different villages of Bansur tehsil of Alwar district. In this area farmers used micro sprinkler irrigation along with high dense plant population and also provide frequent irrigations. The assessment and refinement of technology showed that the seed treatment with metalaxyl 35 SD and two foliar spray of metalaxyl $8 \%+$ mancozeb $64 \%\left(1^{\text {st }}\right.$ at $35-40$ DAS and $2^{\text {nd }}$ spray $65-70$ DAS) along with timely sowing and 3-4 irrigation through sprinkle during the crop season recorded minimum disease intensity (8.2\%) and maximum yield $1875 \mathrm{Kg} / \mathrm{ha}$ as compare to farmers practices (disease intensity $12.05 \%$ and yield $1215 \mathrm{Kg} / \mathrm{ha}$ ). The average economic gross return and cost benefit ratio is also higher in refined technology $\left(\mathrm{T}_{3}\right)$ was Rs 65180 /ha and 1:2.56 followed by treatment $\left(\mathrm{T}_{2}\right)$ Rs 48235 and 1:1.83 as compared with farmers practices Rs 36930 and 1: 1.73 .

\section{Introduction}

In India, oilseed Brassica are grown over an area of about 6.3 million hectares with an annual production of 7.4 million tones with an average yield of $1304 \mathrm{~kg} / \mathrm{ha}$ whereas in Rajasthan it was still $1422 \mathrm{~kg} / \mathrm{ha}(2016-17)$. The severe attack of many diseases not only deteriorates the quality of the seed, but also reduces the oil content considerably. Among the diseases, white rust caused by Albugo candida (Pers. Ex Hook) O. Kuntze, is an important disease of a wide variety of Brassica crops. White rust caused by Albugo candida Kuntze have been reported to be most wide spread and destructive fungal diseases of 
rapeseed mustard throughout the world (Kolte, 1985).It grow fast when favorable climatic minimum temperature of $15-16^{\circ} \mathrm{C}$ maximum temperature of $28-29^{\circ} \mathrm{C}$ and average relative humidity of more than $65 \%$ existed (Sangeetha and Siddaramaiah, 2007).

Its infection causes disfiguring white pustules on leaves, flowers stems and pod leading to yield losses 23 to 54.5 per cent from India (Saharan et al., 1984 and Saharan, 1991) due to both phases (leaf and stag head) and 17-34 per cent (Yadav et al., 2014). Mustard is an economic important crop in Alwar district of Rajasthan more and than 2.5 lac ha area is under mustard cultivation.

Management technology recommended for white rust disease has not much effective because of farmers provide frequent irrigations (4-6) through sprinkler irrigation along with higher seed rate leads dense plant population. Hence, looking for the improve disease management technology. So, there is need of assessment and refinement in technology through on-farm testing.

\section{Materials and Methods}

The study was carried out at in operational area of Krishi Vigyan Kendra (ICARDRMR), Gunta Bansur, Alwar II, Rajasthan. Refinement of technology through on farm testing was conducted in Rabi season 2014-15 and 2015-16 among the 5 different farmers field in each year were selected in different villages of KVK (ICAR-DRMR) GuntaBansur situated at 76.3512220E longitude and $27.6839060 \mathrm{~N}$ latitude. All the farmers were trained on various aspects of mustard crop production and insect pest and disease management.

The observations on progress of disease was recorded from the beginning of first symptoms appears on leaves at farmers field. In each farmers field five plants were selected random, labeled and white rust intensity were recorded at seven days interval starting from the date of sowing on leaves using 0 - 5 scale as described below.

The Percent Disease Index (PDI) was calculated using the formula (Wheeler, 1969).

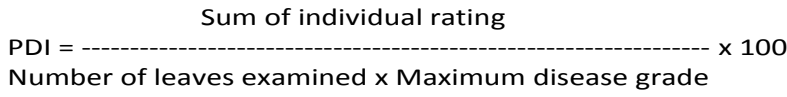

\section{Scale Description of the symptom}

0 Leaves free from infection

1 Small white raised rust pustules covering $<5 \%$ leaf area

2 Small white raised rust pustules covering 5.1$10 \%$ leaf area

3 Small white raised rust pustules join together covering 10.1-25\% leaf area

4 Small white raised rust pustules join together to form irregular patches covering 25.1-50\% leaf area

5 Small white raised rust pustules join together to form irregular large patches covering $<50 \%$ leaf area

$\mathrm{T}_{1}=$ Late sowing, no seed treatment and frequent irrigation (4-6) by sprinkle

$\mathrm{T}_{2}=$ Seed treatment with metalaxyl $35 \mathrm{SD} @ 6 \mathrm{~g} / \mathrm{kg}$ seed and foliar sprays of mancozeb @ 3g/l of water)

$\mathrm{T}_{3}=$ Seed treatment with metalaxyl 35\% SD @ 6g/kg of seed and foliar spray of metalaxyl $8 \%$ + mancozeb $64 \%\left(1^{\text {st }}\right.$ at $35-$ 40 DAS and $2^{\text {nd }}$ spray 65-70 DAS) with 3-4 irrigation through sprinkle.

To know the effect of different treatments on crop yield, thousand seed wt, oil content and cost-benefit ration. The harvest from various treatments were separately harvested and threshed and average yield per hectare and cost-benefit ratio were calculated. The seed obtained from each treatment was also analyzed for oil content with standard chemical methods.

\section{Results and Discussion}

\section{Symptoms}

There are two types of infection were observed on different plant parts such as leaves, stem and inflorescence, first localized 
infection of white rust disease on leaves and second Systemic infection on inflorescence. At farmers' fields in natural conditions symptoms was observed as early as 35-40 DAS mostly under surface of the lower leaves in the form of small creamy white spot either singly spot at one place or many small spot at many places on same leave depending upon the soil moisture and relative humidity of the environment.

Systemic infection results in abnormal growth and distortion of inflorescence and sterility of flowers, commonly called stag head formed as a result of hypertrophy and hyperplasia. The epidemic development of white rust caused by $A$. candida is dependent upon many factors, viz. aggressiveness of race, amount of available initial inoculums, time of first appearance of the disease and prevailing weather conditions. A. candida isolates from different Brassica species/cultivar or from different geographical regions may be different in their incubation period, latent period and production of sporangia and zoospores, pustule size, shape and texture and aggressiveness (Lakra and Saharan, 1988; Gupta and Saharan, 2002; Patni et al., 2005 and Mishra et al., 2009).

Spot also in ring form. When disease advanced the spot are collapsed together. The whole leaves appeared as white pustules of Albugo candida. The symptoms also appear on stem or pod when disease appears earlier in filed. In mixed infection of white rust and downy mildew is common on stage heads

\section{Effect of different treatments on white rust severity}

The assessment and refined of technology showed that the treatment $\mathrm{T}_{3}$ i.e. seed treatment with Metalaxyl 35\% SD @ 6g/Kg of Seed and foliar spray of Metalaxyl $8 \%+$ Mancozeb $64 \%\left(1^{\text {st }}\right.$ at $35-40$ DAS and $2^{\text {nd }}$ spray 65-70 DAS) along with timely sowing and 3-4 irrigation through sprinkle during the crop season recorded minimum disease severity $(8.25 \%)$ and maximum disease control 31.5 per cent followed by treatment $\mathrm{T}_{2}$ (i.e. seed treatment with Metalaxyl 35 SD @ $6 \mathrm{~g} / \mathrm{kg}$ seed and foliar spray of Mancozeb @ $3 \mathrm{~g} / \mathrm{l}$ of water) was disease severity $(9.65 \%)$ and disease control 19.92 per cent as compare to farmers practices in which disease severity was 12.05 per cent.

\section{Seed yield and cost benefit ratio}

Mean of 2 years data on seed yield and cost benefit ratio presented in table 2 showed that the maximum seed yield (1875 Kg/ha) was obtained in treatment $\mathrm{T}_{3}$ i.e. metalaxyl $35 \%$ SD @ $6 \mathrm{~g} / \mathrm{kg}$ of Seed and foliar spray of Metalaxyl 8\% + Mancozeb 64\% which was $54.3 \%$ higher seed yield as compare to farmers practices $(1215 \mathrm{Kg} / \mathrm{ha})$ followed by treatment $\mathrm{T}_{2}$ (seed treatment with Metalaxyl 35 SD @ 6g/kg seed and foliar spray of Mancozeb @ 3g/l) the seed yield was 1400.0 $\mathrm{Kg} / \mathrm{ha}$.

The average economic gross return and cost benefit ratio is also higher in refined technology $\left(\mathrm{T}_{3}\right)$ was Rs 65180 /ha and 1:2.56 followed by treatment $\left(\mathrm{T}_{2}\right) \mathrm{Rs} 48235$ and 1:1.83 as compared with farmers practices Rs 36930 and 1: 1.73. The result was collaborated with result of Abhishek et al., (2014).

\section{Effect of different treatments on 1000 seed weight and oil contents}

Maximum 1000 seed weight was $5.2 \mathrm{~g}$ and oil content $(39.6 \%)$ were recorded in treatment $\mathrm{T}_{3}$ followed by treatment $\mathrm{T}_{2}(4.8 \mathrm{~g}$ and $38.3 \%)$ and minimum recorded in Farmers practices (3.88g and 37.2\%) (Table 3). The finding was collaborated with Bains and Jhooty (1979) reported losses in B. juncea from $37-47 \%$ and $17-32 \%$ reduction in siliquae formation and seed production respectively due to mixed infection of DM and white rust. 
Table.1 Effect of different treatments on the White rust severity at farmers' fields during the year 2014-15 and 2015-16

\begin{tabular}{|l|c|c|c|c|}
\hline Treatments & \multicolumn{3}{|c|}{ Disease severity (\%) } & $\begin{array}{c}\text { Disease control } \\
\text { over Farmer } \\
\text { practices (\%) }\end{array}$ \\
\hline $\begin{array}{l}\text { T1 : Farmers practices: Late } \\
\text { sowing, no seed treatment and frequent } \\
\text { irrigation by sprinkle }\end{array}$ & 12.6 & 11.5 & 12.05 & - \\
\hline $\begin{array}{l}\text { T2 : Recommended practice: } \\
\text { Seed treatment with Metalaxyl 35 SD } \\
\text { and FS Mancozeb @ 3g/l }\end{array}$ & 9.2 & 10.1 & 9.65 & 19.92 \\
\hline $\begin{array}{l}\text { T3: Refinement in technology: } \\
\text { Timely sowing + ST and FS of } \\
\text { Metalaxyl 8\%+ Mancozeb 64\% @ 2g/l }\end{array}$ & & & & \\
\hline CD at (0.05) & 8.4 & 8.1 & 8.25 & \\
\hline CV & & & & \\
\hline
\end{tabular}

Table.2 Effect of different treatments on seed yield and cost benefit ratio of mustard at farmer field

\begin{tabular}{|c|c|c|c|c|c|c|c|c|}
\hline \multirow[t]{2}{*}{ Treatments } & \multicolumn{3}{|c|}{ Yield (Kg/ha) } & \multirow{2}{*}{$\begin{array}{l}\text { Mean } \\
\text { Yield } \\
\text { increases } \\
\text { Over FP } \\
(\%)\end{array}$} & \multirow{2}{*}{$\begin{array}{l}\text { Av.Cost of } \\
\text { Cultivation( } \\
\text { Rs/ha) }\end{array}$} & \multirow[b]{2}{*}{$\begin{array}{l}\text { Av. } \\
\text { Gross } \\
\text { return } \\
\text { (Profit) } \\
\text { Rs./ha }\end{array}$} & \multirow{2}{*}{$\begin{array}{l}\text { Av. Net } \\
\text { Return }\end{array}$} & \multirow[t]{2}{*}{ B:C Ratio } \\
\hline & 2014-15 & 2015-16 & Mean & & & & & \\
\hline T1 & 1200 & 1215 & 1250 & - & 21370 & 36930 & 15560 & $1: 1.73$ \\
\hline $\mathbf{T} 2$ & 1420 & 1380 & 1400 & 15.7 & 26370 & 48235 & 21865 & 1.1 .83 \\
\hline T3 & 1840 & 1910 & 1875 & 54.5 & 25470 & 65180 & 39710 & $1: 2.56$ \\
\hline CD at(0.05) & & & 106.54 & & - & & & - \\
\hline CV & & & 4.88 & & & & & \\
\hline
\end{tabular}

Table.3 Effect of different treatments on 1000 seed weight and oil content in mustard seed at farmer field during the year 2014-15 and 2015-16

\begin{tabular}{|l|c|c|c|c|c|c|}
\hline \multirow{2}{*}{ Treatments } & \multicolumn{3}{|c|}{$\mathbf{1 0 0 0}$ seed wt(g) } & \multicolumn{3}{c|}{ Oil content (\%) } \\
\cline { 2 - 7 } & $\mathbf{2 0 1 4 - 1 5}$ & $\mathbf{2 0 1 5 - 1 6}$ & $\begin{array}{c}\text { Av. Seed } \\
\text { wt(g) }\end{array}$ & $\mathbf{2 0 1 4 - 1 5}$ & $\mathbf{2 0 1 5 - 1 6}$ & $\begin{array}{c}\text { Av. Oil } \\
\text { content }\end{array}$ \\
\hline T1: & 3.85 & 3.91 & 3.88 & 36.8 & 37.7 & 37.2 \\
\hline T2: & 4.78 & 4.83 & 4.80 & 38.2 & 38.5 & 38.3 \\
\hline T3: & 5.21 & 5.20 & 5.20 & 39.5 & 39.8 & 39.6 \\
\hline CV & & & 3.22 & & & 0.967 \\
\hline CD at $(\mathbf{0 . 0 5})$ & & & 0.217 & & & 0.542 \\
\hline
\end{tabular}


Fig.1

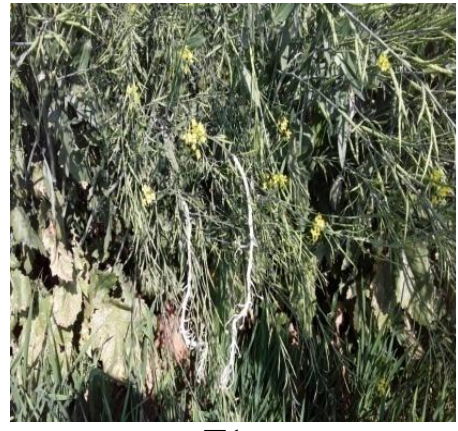

T1

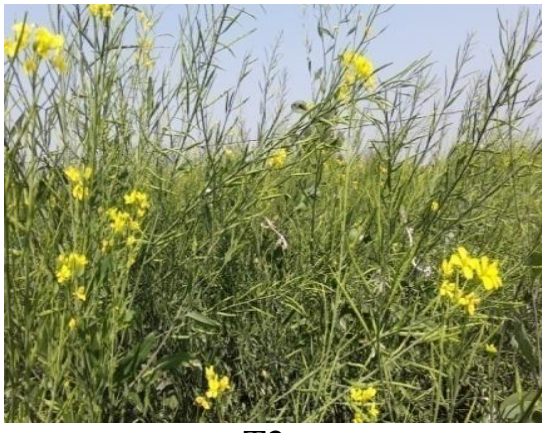

$\mathrm{T} 2$

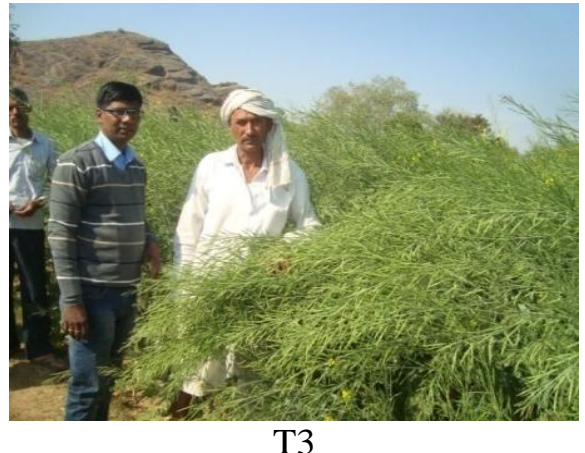

T3
PD Meena (2014) reported that on the 1000seed weight, the per cent yield reductions were 46.8, 42.6 and 66.7 in cvs. Varuna, Rohini and NRCDR-2, respectively. Others workers have also reported $23-55 \%$ yield loss in B. juncea due to mixed infection with both pathogens (Saharan, 1992).

In conclusion the management technology recommended for white rust disease was seed treatment with Metalaxyl 35\% SD @ 6g/Kg of Seed and foliar spray of Metalaxyl $8 \%+$ Mancozeb $64 \%\left(1^{\text {st }}\right.$ at $35-40$ DAS and $2^{\text {nd }}$ spray 65-70 DAS) along with timely sowing and 3-4 irrigation through sprinkle method was found to be effective in disease control with higher production of mustard with high oil content percentage.

\section{Acknowledgement}

The authors are highly grateful to ICAR, ATARI II and Director, ICAR-Directorate of Rapeseed-Mustard, Sewar, Bharatpur to conduct On Farm Trail successfully at KVK.

\section{References}

Abhishek, Rajendra Prasad, Dushyant Kumar, Virendra Kumar, Maneesh Kumar and Deepak Kumar., 2017. Symptoms and Management of White Rust/ Blister of Indian Mustard (Albugo candida). Int.J.Curr.Microbiol.App.Sci. $\quad$ 6(10):
1094-1100.

Bains, SS and Jhooty, JS., 1979. Mixed infections by Albugo candida and Peronospora parasitica on Brassica juncea inflorescence and their control. Indian Phytopathol 32: 268-271.

Gupta, K., and Saharan, G.S., 2002. Identification of pathotype of Albugo candida with stable characteristic symptoms on Indian mustard. J. Mycol. Pl. Pathol. 32: 46-51

Kolte, S.J., 1985. Diseases of Annual Edible Oilseed Crops, Vol. II, Rapeseed Mustard and Sesame Diseases. CRC Press Inc. Boca Raton, Florida, USA, p. 135.

Mishra, K.K., Kolte, S.J. Nashaat, N.I. and Awasthi, R.P., 2009. Pathological and biochemical changes in Brassica juncea (mustard) infected with Albugo candida (white rust). Pl. Pathol. 58: 80-86.

Patni, C.S., Singh, A. and Awasthi, R.P., 2005. Variability in Albugo candida causing white rust disease of rapeseedmustard. J. Res. 4: 20-24.

PD Meena, Lijo Thomas and Dhiraj Singh., 2014. Assessment of yield losses in Brassica juncea due to downy mildew (Hyaloperonospora brassicae). Journal of Oilseed Brassica 5(1): 73-77.

Saharan, G.S., 1991. Assessment of losses, epidemiology and management of black spot disease of rapeseed-mustard. Proc. GCIRC 8th Int. Rapeseed Congr, 
Saskatoon, Canada, p 84 (Abstr.). Vol. 2, 465-470.

Saharan, G.S., Kaushik, C.D. Gupta, P.P. and Tripathi, N.N., 1984. Assessment of losses and control of white rust of mustard. Indian Phytopath. 37, 397.

Saharan, GS., 1992. Management of rapeseed and mustard diseases. In: Kumar, D., Rai, M. (Eds.) Advances in Oilseed Research. Scientific publishers, Jodhpur, 152-188 pp

Sangeetha, C.G. and A. L. Siddaramaiah.,
2007. Epidemiological studies of white rust, downy mildew and Alternaria blight of Indian mustard (Brassica juncea (Linn.) Czern. and Coss.). African Journal of Agricultural Research Vol. 2 (7), pp. 305-308

Yadav, R.B., Kumar, A. Kumar, A. and Verma, S.K., 2014. Screening of rapeseed-mustard cultivars/lines for resistance against alternaria blight. Indian J. Sci. Res. 5(1): 89-91.

\section{How to cite this article:}

Sunil Kumar, Sushil Kumar Sharma, Pankaj Sharma and Rai, P. K. 2020. Study of White Rust (Albugo candida) Management Approach in Indian Mustard (Brassica juncea) at Farmers Fields through on farm Trail (OFT). Int.J.Curr.Microbiol.App.Sci. 9(10): 3916-3921. doi: https://doi.org/10.20546/ijcmas.2020.910.451 